\title{
Bacterioplankton abundance and growth in a river-dominated estuary: relationships with temperature and resources
}

\author{
George B. McManus ${ }^{1, *}$, Patrick M. Griffin ${ }^{2}$, Jonathan R. Pennock ${ }^{3}$ \\ ${ }^{1}$ Department of Marine Sciences, University of Connecticut, Groton, Connecticut 06340, USA \\ ${ }^{2}$ Dauphin Island Sea Lab, University of South Alabama, Dauphin Island, Alabama 36528, USA \\ ${ }^{3}$ Marine Program, University of New Hampshire, Durham, New Hampshire 03824, USA
}

\begin{abstract}
We measured bacterial abundance and productivity, along with other biological, chemical, and physical variables, during a 17 mo study in Mobile Bay, USA. Mobile Bay is a shallow, riverdominated estuary, with highly variable freshwater inputs and relatively short freshwater residence time (ca. 2 to $3 \mathrm{wk}$ ). In addition to the field measurements, we performed bioassay experiments to evaluate the degree of resource limitation of the bacterioplankton. As in other seasonally variable estuaries, temperature appeared to be an important regulator of bacterioplankton in Mobile Bay, with minima in abundance and growth rates occurring during winter. The bioassay experiments, in which an inoculum of the natural bacterioplankton community was diluted into filtered bay water and incubated for $4 \mathrm{~d}$, always resulted in rapid net growth, indicating the presence of labile substrates. The net yield of bacterial cells in these assays was always equal to or greater than the abundance of in situ populations, suggesting that an amount of substrate about equal to in situ biomass divided by growth efficiency was present year round. During winter, the yields in the bioassays were highest, suggesting an accumulation of resources when bacterial growth was limited by temperature.
\end{abstract}

KEY WORDS: Bacteria $\cdot$ Mobile Bay $\cdot$ Gulf of Mexico $\cdot$ Thymidine $\cdot$ Epifluorescence $\cdot$ Seawater culture

\section{INTRODUCTION}

Estimates of bacterial production in estuaries are probably more numerous than those of any other marine ecosystem (Ducklow \& Shiah 1993). Yet, because of the great heterogeneity among estuaries in terms of circulation, physical forcings, nutrient loadings, climate, and other factors, few generalizations can be made about this important trophic flow. The role of bacteria in estuaries has received so much attention in part because of eutrophication and the increasing duration and extent of hypoxia in urbanized estuaries worldwide. Although the principal direct effect of eutrophication is to stimulate phytoplankton production, the consequent increased flux into the dissolved organic carbon (DOC) pool often leads to increased oxygen demand by heterotrophs. As they dominate the metabolism, and at times the biomass, of heterotrophic plankton, bacteria in the water column are a direct agent of oxygen decline. Understanding how bacterioplankton metabolism will respond to the decreased phytoplankton production that is expected to accompany reductions in nutrient loading to estuaries is thus critical to the design of effective management strategies for water quality improvement. Likewise, estuaries are important as producers, processors, and exporters of organic matter, and the role of bacteria in the interactions between estuaries and shelf or oceanic systems has not been quantified for many systems. These trophic processes are critical to understanding overall nearshore productivity.

The increased autochthonous DOC (phytoplankton production) in estuaries resulting from anthropogenic nutrient inputs is often superimposed on a large natural input of DOC derived from the watershed. Neither of these 2 pools of DOC is well understood chemically, so 
it is difficult to evaluate their relative importance as sources of potential bacterial substrates. In addition to this, the nature and quantity of DOC may vary over time in an estuary, due to changes in autochthonous productivity caused by local factors (mixing, light) or to allochthonous inputs caused by larger-scale forcings (seasonal or interannual variations in freshwater discharge, changes in watershed land use, shelf-estuary water exchange; Guo et al. 1999). In some cases, inorganic nutrients may limit bacterial metabolism of DOC, depending on $\mathrm{C}: \mathrm{N}$ in dissolved organic matter and the availability of organic nitrogen (Kirchman et al. 1989, Pace \& Cole 1996). Thus, estuarine ecologists have resorted to empirical or experimental (e.g. bioassays) approaches, or to simulation models, to evaluate environmental controls on bacterial metabolism.

We used a combination of field observations and bioassay experiments to evaluate the effects of environmental factors and resources on bacterial productivity in Mobile Bay, USA. Mobile Bay is located in the northern Gulf of Mexico, east of the Mississippi River. It has an average width of $17 \mathrm{~km}$ and average depth of $3 \mathrm{~m}$, except for a narrow ship channel that reaches a maximum depth of $15 \mathrm{~m}$ (Pennock et al. 1994). Input of fresh water comes from the Tombigbee and Alabama rivers and averages $1848 \mathrm{~m}^{3} \mathrm{~s}^{-1}$, though a strong

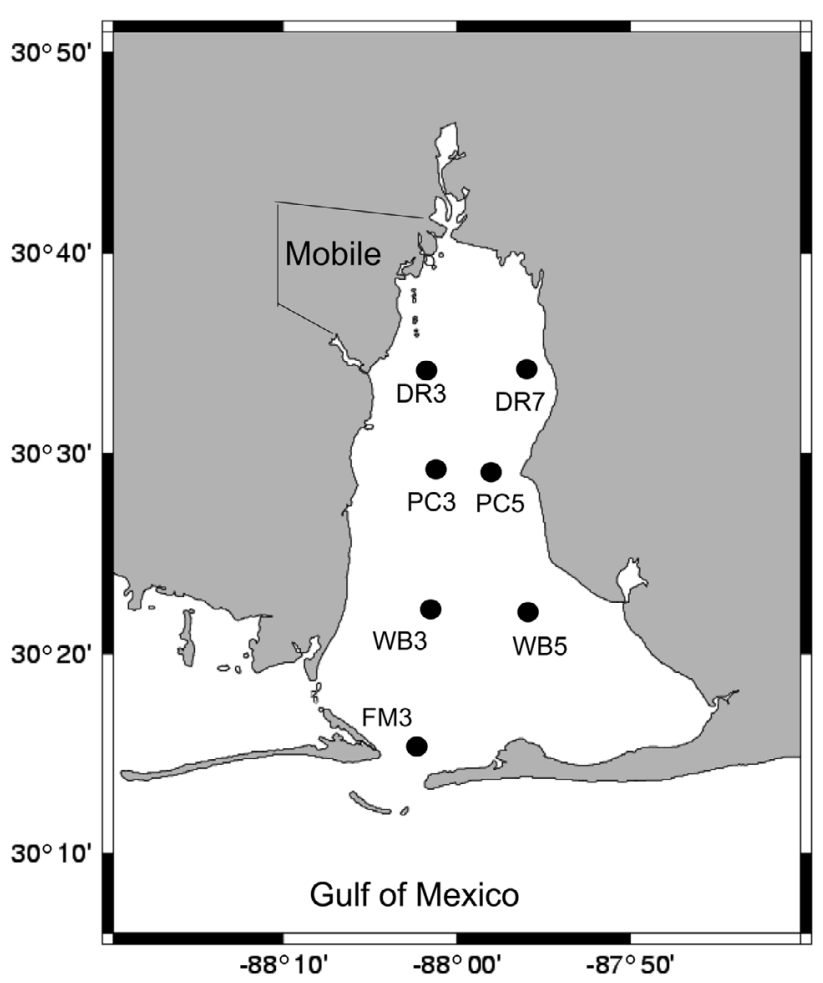

Fig. 1. Station locations in Mobile Bay. Stations with the number 3 in the name are in the channel seasonality exists; peak flows are about $7000 \mathrm{~m}^{3} \mathrm{~s}^{-1}$ (Schroeder \& Wiseman 1986). Over the length of the bay, the large freshwater input results in low salinity surface waters in the upper and mid-bay, ranging from 0 to 10 (practical salinity scale), while a salinity range of 5 to 25 is present in surface waters near the mouth of the bay. Water temperatures range from near $10^{\circ} \mathrm{C}$ in the winter, to greater than $30^{\circ} \mathrm{C}$ during summer. Thermal stratification is not common given the shallowness of the bay, but salinity stratification can be strong at times, depending on freshwater inputs and storm frequency (Schroeder \& Wiseman 1986, Wiseman et al. 1988, Pennock et al. 1994).

\section{MATERIALS AND METHODS}

The study site consisted of 7 stations, 4 located in the shipping channel and 3 located on the east side of the bay in water $\sim 3 \mathrm{~m}$ deep. The 7 stations represented 2 upper bay sites, 4 middle bay sites, and 1 lower bay site (Fig. 1). Water samples were taken approximately monthly from March 1994 through August 1995. Surface water was collected in 2.31 polycarbonate bottles submerged by hand just below the surface. After subsamples for bacterial abundance had been taken and preserved, the bottles were kept on ice in an insulated cooler and returned to the laboratory for processing within $5 \mathrm{~h}$. A Hydrolab temperature/conductivity meter was used to measure temperature and salinity. Underwater light was measured using a LiCor quantum irradiance meter with spherical deck and underwater sensors. Chlorophyll a ( $\mathrm{chl}$ a) was measured fluorometrically in $90 \%$ acetone extracts of material collected on glass fiber filters (Whatman GF/C), corrected for phaeopigments (Strickland \& Parsons 1972). Primary productivity rates were measured in $24 \mathrm{~h}$ incubations. Polycarbonate bottles $(125 \mathrm{ml})$ were spiked with $0.5 \mathrm{mCi} \mathrm{NaH}{ }^{14} \mathrm{CO}_{3}$ and incubated in natural light $(100,64,36,21,9.4$, and $2.1 \%$ ambient) in an outdoor incubator with flowing surface bay water for temperature control (Pennock \& Sharp 1986). Areal production was determined by integrating the ${ }^{14} \mathrm{C}$ incorporation obtained at each of the light levels described by the diffuse attenuation coefficient. Inorganic nutrients were measured with an Alpkem RFA/2 autoanalyzer using standard wet chemical methods (Strickland \& Parsons 1972). Dissolved organic carbon (DOC; GF/C filtrate) was measured by high-temperature catalytic oxidation on a Shimadzu TOC-5000 total organic carbon analyzer. Dissolved organic nitrogen (DON) and phosphorus (DOP) were measured using standard methods, as described in Cowan et al. (1996).

Data on daily freshwater discharge into the Bay were obtained from the US Geological Survey gaging 
stations on the Alabama and Tombigbee rivers (data provided by the Dauphin Island Sea Lab).

Bacterial abundance. Samples for bacterial counts were transferred immediately into $20 \mathrm{ml}$ glass scintillation vials and fixed with $0.6 \%$ (final concentration) filtered formaldehyde. Fixed samples were kept on ice during transport to the laboratory. Bacterial abundance was determined by the acridine orange direct count method (Hobbie et al. 1977). One ml of sample water was stained with $100 \mu \mathrm{l}$ of $0.1 \%$ acridine orange for $1 \mathrm{~min}$, then filtered through a pre-stained black $0.2 \mu \mathrm{m}$ Nuclepore polycarbonate membrane under gentle vacuum. Filters were mounted on glass slides with Cargille's Type A immersion oil. Bacteria were enumerated on an Olympus BX 50 epifluorescence microscope at $1250 \times$ magnification.

Bacterial production. From September 1994 through August 1995, bacterial production was estimated using the tritiated thymidine incorporation $\left({ }^{3} \mathrm{H}\right.$ TdR) technique (Fuhrman \& Azam 1982, Bell 1993). Triplicate samples of $10 \mathrm{ml}$ plus 1 formalin-killed control from each station were pipetted into $15 \mathrm{ml}$ centrifuge tubes. In total, $100 \mu \mathrm{l}$ of ${ }^{3} \mathrm{H}$ TdR at $0.1 \mathrm{mCi}^{-1}$ was added to each sample, producing a $10 \mathrm{nM}$ TdR final concentration. Preliminary experiments showed that $10 \mathrm{nM}$ TdR was enough to saturate thymidine uptake by bacteria in Mobile Bay. Samples were incubated at in situ temperature for 0.5 to $1 \mathrm{~h}$ depending on the season. The incubations were stopped by adding $125 \mu$ of filtered formalin, then $1 \mathrm{ml}$ of ice cold $50 \%$ trichloracetic acid (TCA) was added to each sample to obtain a $5 \%$ final TCA concentration. The killed samples were placed on ice for $15 \mathrm{~min}$, then filtered through a $0.45 \mu \mathrm{m}$ cellulose acetate membrane filter, which had been presoaked in $1 \mathrm{mM}$ non-radioactive thymidine to reduce ${ }^{3} \mathrm{H} \mathrm{TdR}$ adsorption. The filters were rinsed 5 times with $5 \%$ ice cold TCA while under gentle vacuum, and then transferred to $20 \mathrm{ml}$ glass scintillation vials where $1 \mathrm{ml}$ of ethyl acetate was added to each, followed by $10 \mathrm{ml}$ of Ready Safe scintillation cocktail. Radioactivity was measured by liquid scintillation spectroscopy with quench correction using external standards. The rates of thymidine incorporation were converted to carbon production rates using conversions of $2 \times 10^{18}$ cells $\mathrm{mol}^{-1} \mathrm{TdR}$ and $20 \times 10^{-15} \mathrm{~g} \mathrm{C}$ cell $^{-1}$ (Fuhrman \& Azam 1982; Lee \& Fuhrman 1987; Ducklow \& Shiah 1993).

For comparison with vertically-integrated primary production ( $\mathrm{mg} \mathrm{C} \mathrm{m}^{-2} \mathrm{~d}^{-1}$ ), bacterial production (mg C $\mathrm{m}^{-3} \mathrm{~d}^{-1}$ ) in shallow stations was multiplied by the depth of the water column. Bacterial production at stations located within the ship channel was integrated to the halocline depth $(\sim 4 \mathrm{~m})$. Intrinsic growth rates were calculated as production divided by biomass.

Seawater culture experiments. From August 1994 through August 1995, 'seawater culture' experiments were performed approximately monthly as bioassays to evaluate availability of dissolved nutrients for bacterial growth (cf. Ammerman et al. 1984, Sondergaard \& Middelboe 1995). Surface water from 3 stations representing upper, mid-, and lower bay sites was collected in 2.31 polycarbonate bottles and transported on ice to the laboratory. One 1 of water from each station was pre-filtered through a Whatman GF/F filter to remove large particulate matter; from that, $900 \mathrm{ml}$ was filtered through a $0.45 \mu \mathrm{m}$ cellulose acetate membrane filter to remove bacteria. Another $100 \mathrm{ml}$ of sample water was filtered through a $0.6 \mu \mathrm{m}$ Nuclepore polycarbonate filter to remove bacterial grazers, leaving most of the natural bacterial population intact. In duplicate experiments, $50 \mathrm{ml}$ of this water was combined with $450 \mathrm{ml}$ of the bacteria-free water in a Whirlpak plastic bag, diluting bacteria to approximately $10 \%$ of in situ abundance. The seawater cultures were incubated at $20^{\circ} \mathrm{C}$ in darkness for several days. Our goal was to estimate the amount of labile organic resources available for bacterial growth as final biomass yield divided by growth efficiency. We chose to incubate all samples at a single temperature rather than at in situ temperatures because there is evidence that growth efficiency in natural bacterioplankton communities varies with temperature (Daneri et al. 1994). Periodic samples of $10 \mathrm{ml}$ were taken (typically at 0, 24, 48, 72, and $90 \mathrm{~h}$ ), killed with formalin, and enumerated by fluorescence microscopy, as above. Net yield was determined by subtracting the time 0 count from the highest abundance during the experiment, normally at $72 \mathrm{~h}$.

Seawater culture enrichment experiments. During June, July and August of 1995, we performed 3 experiments to evaluate nutrient limitation of final yield during the seawater culture incubations. In the first 2 experiments, we sampled at the lower bay station (FM3) and a station $5 \mathrm{~km}$ to the east of mid-bay station WB5. For these experiments, we added several nutrient addition treatments to the standard set of seawater culture incubations. Treatments were no addition (control), phosphate addition $\left(\mathrm{Na}_{2} \mathrm{HPO}_{4} ; 0.6 \mu \mathrm{M}\right)$, or ammonium $\left(\mathrm{NH}_{4} \mathrm{Cl}_{i} 2 \mu \mathrm{M}\right)$ plus phosphate addition. These were prepared and incubated according to the standard seawater culture procedure described above. The third experiment, in August, followed a different protocol. For this experiment, we sampled at the same 2 stations as in June and July, but added a third station located in the open Gulf of Mexico, $10 \mathrm{~km}$ outside the Bay. Duplicate samples from each station were inoculated and incubated as seawater cultures according to our normal procedure. At the end of the incubation period, however, when bacterial populations had stopped growing, we collected samples for bacterial counts and then added nutrients in 5 treatments. These were no addition (control), ammonium $\left(\mathrm{NH}_{4} \mathrm{Cl}_{;} 2 \mu \mathrm{M}\right)$, 
phosphate $(0.6 \mu \mathrm{M})$, ammonium plus phosphate, or glucose $(1 \mathrm{mM})$. These treatments were incubated and sampled for an additional $72 \mathrm{~h}$; then, bacteria were counted and any additional yield was calculated.

Statistical methods. For the nutrient addition experiments, single-factor analysis of variance (ANOVA) was performed to test for added variance among treatments, using Microsoft Excel with $\alpha=0.05$. Regression and correlation analyses for the field data were performed using SigmaPlot.

\section{RESULTS}

The 2 yr of our study were typical in terms of precipitation and hydrography (Fig. 2A) (Schroeder \& Wiseman 1986, Wiseman et al. 1988, Pennock et al. 1994). Peak freshwater discharge occurred in late winter/ early spring and was lowest in summer, which had episodic inputs from storms. Water temperature at the
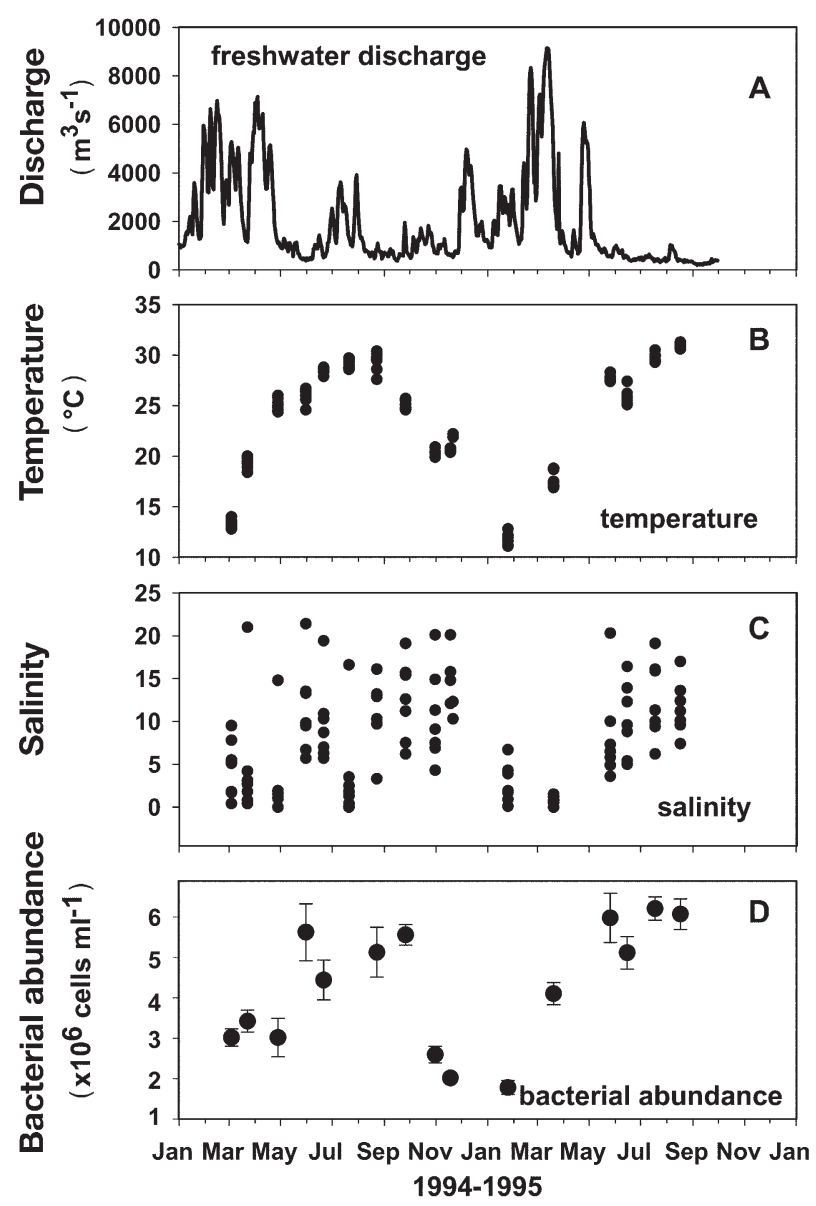

Fig. 2. (A) Daily freshwater discharge, (B) temperature, (C) salinity, and (D) bacterial abundance $( \pm$ SE among stations) during the study period. Salinity is plotted on the practical salinity scale (pss) surface ranged from $11^{\circ} \mathrm{C}$ in mid-winter to $31^{\circ} \mathrm{C}$ in August (Fig. 2B).

The annual peak in mean monthly discharge was slightly lagging the temperature minimum, and minimum discharge occurred when temperature was at its highest (Fig. 2). The annual discharge cycle resulted in a large salinity range in the Bay, with the variance among stations being greatest at low discharge and the Bay being nearly fresh throughout when discharge was highest (e.g. 0 to 1.5 range in salinity among all 7 stations in March 1995; Fig. 2C).

Abundance of bacterioplankton followed temperature closely, ranging from a low of $1.78 \times 10^{6} \mathrm{cells} \mathrm{ml}^{-1}$ $\left( \pm 0.17 \times 10^{6} \mathrm{SE}_{\text {; }}\right.$ average for all stations $)$ in January 1995 to a high of $6.21 \times 10^{6}$ cells ml ${ }^{-1}\left( \pm 0.29 \times 10^{6} \mathrm{SE}\right)$ in July 1995 (Fig. 2D).

Chl a did not show marked seasonality, fluctuating around $10 \mu \mathrm{g} \mathrm{l}^{-1}$ for most of the year, with occasional spikes due to blooms in the shallow waters on the eastern side of the mid-bay region (Fig. 3A). Phosphate and

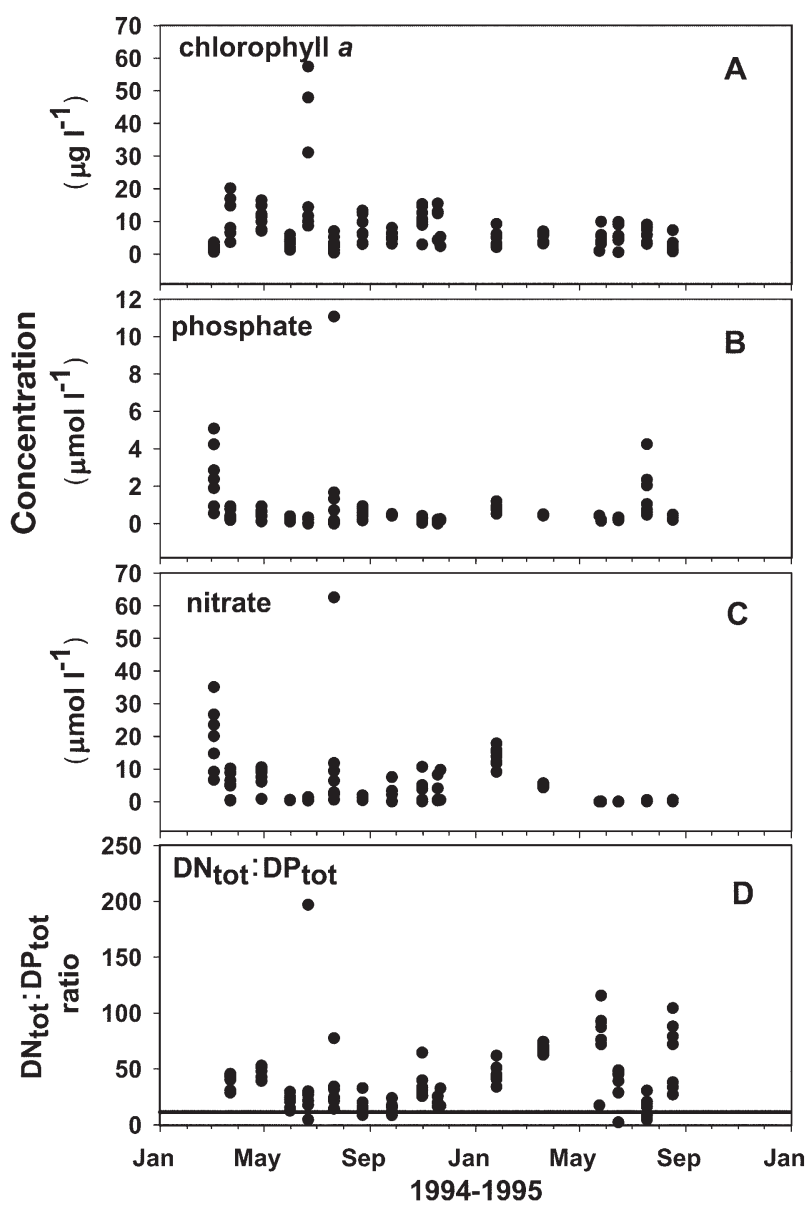

Fig. 3. (A) Chl $a$, (B) phosphate, (C) nitrate, and (D) total dissolved nitrogen:total dissolved phosphorus (organic plus inorganic) during the study period. Horizontal line in (D) illustrates an N:P of 10, the value in bacterial cells 
nitrate were generally low in concentration $(<0.5$ and $<10 \mu \mathrm{M}$, respectively; Fig. 3B,C), except during periods of high discharge. The ratio of total dissolved nitrogen to total dissolved phosphorous (inorganic plus organic) almost always exceeded 10, the canonical value for bacterial cell content (Fig. 3D; Stanier et al. 1970).

Primary production (0 to $3500 \mathrm{mg} \mathrm{C} \mathrm{m}^{-2} \mathrm{~d}^{-1}$ ) often showed strong variation among stations but, like chl $a$, exhibited seasonality only in the sense that it was lower during the winter/spring peak in discharge when the salinity was at its annual minimum (Fig. 4A).

Dissolved organic carbon (DOC) was relatively constant across the seasons, varying by less than a factor of 3 , from $284 \pm 10$ to $792 \pm 173 \mu \mathrm{mol} \mathrm{l}^{-1}$ (mean $\pm \mathrm{SE}_{\text {; }}$ averaged over all stations on each sampling date) over the entire $2 \mathrm{yr}$ of the study (Fig. 4B).

Bacterial intrinsic growth rates and production, like bacterial abundance, peaked in summer and were lowest in winter. These properties varied by a factor of $\sim 1.5$ to 5 among stations within a sampling date (Fig. 4D).

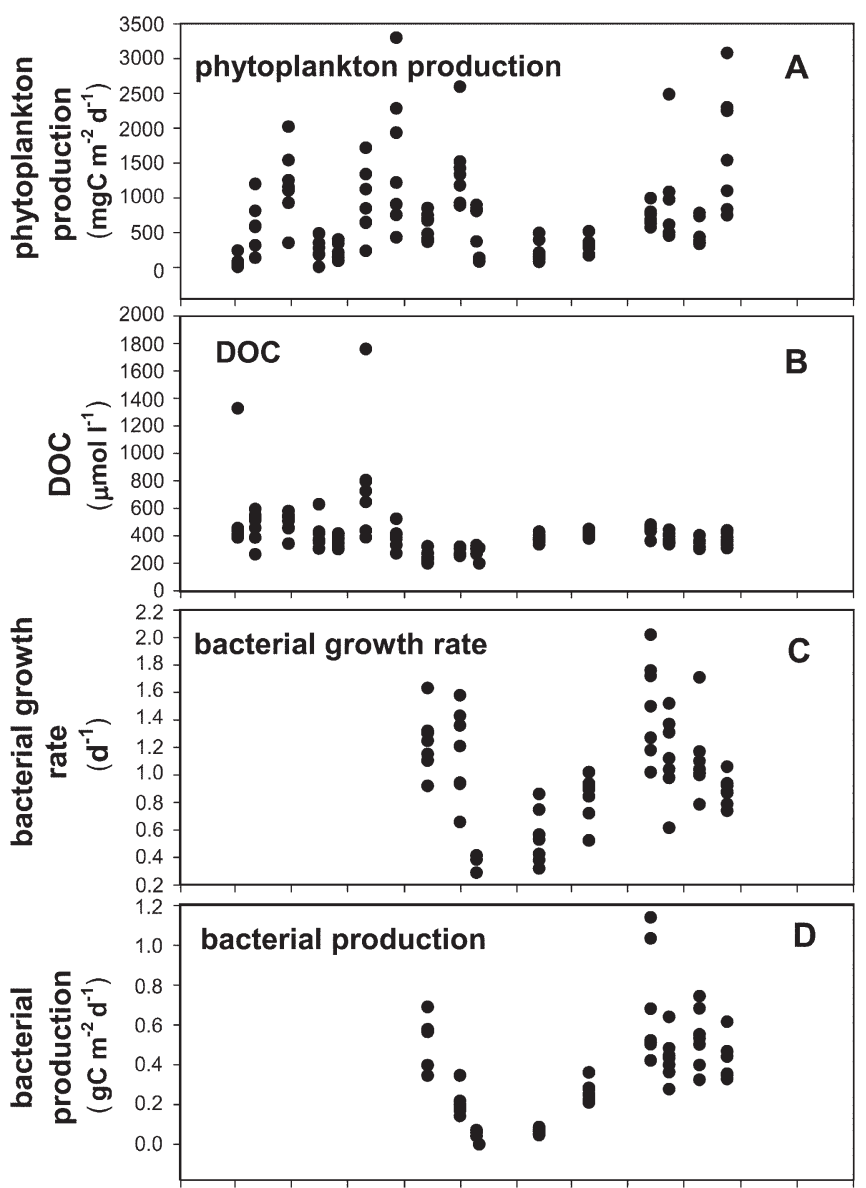

Jan Mar May Jul Sep Nov Jan Mar May Jul Sep Nov Jan 1994-1995

Fig. 4. (A) Phytoplankton production, (B) dissolved organic carbon, (C) bacterial intrinsic growth rates, and (D) bacterial production during the study period
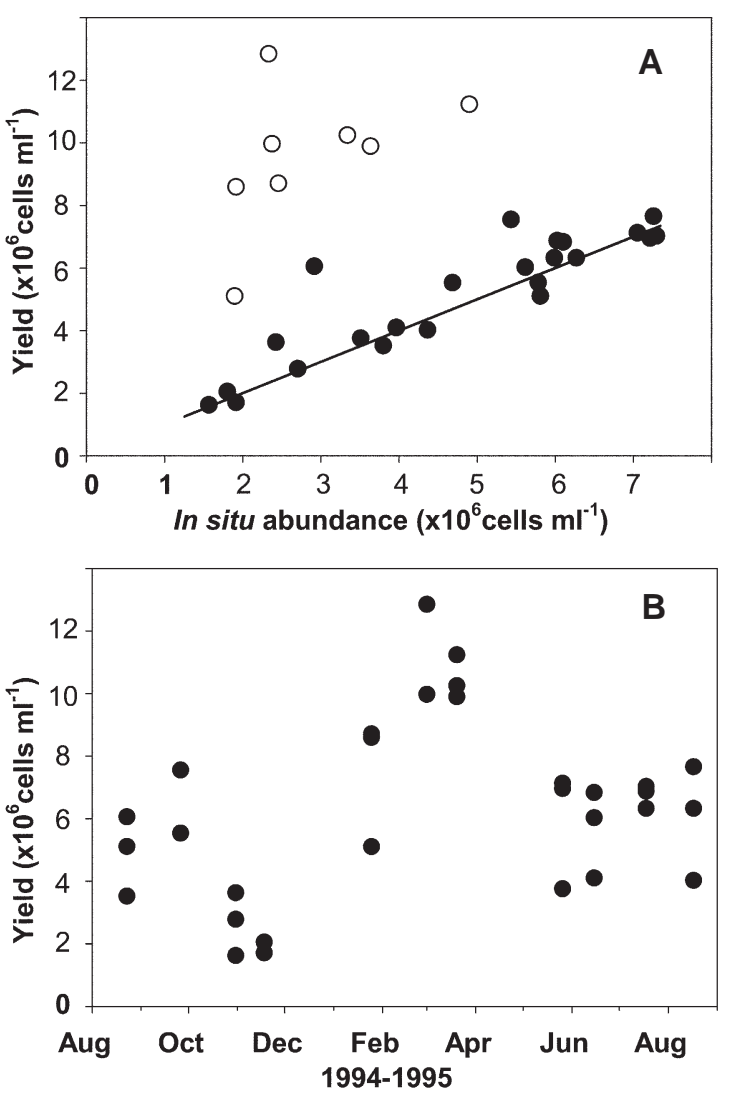

Fig. 5. Yields of seawater cultures versus (A) in situ abundance and (B) time. Data at in situ temperatures $<20^{\circ} \mathrm{C}$ are shown (O) in (A). Line is $x=y$

The seawater culture experiments always resulted in net bacterial growth. Bacterial populations increased rapidly in the incubations, regardless of season (Fig. 5). When the yields in our seawater cultures are compared to in situ abundances at the same station and on the same date, these 2 properties are strongly correlated for in situ temperatures of $20^{\circ} \mathrm{C}$ or greater $(\mathrm{r}=0.90 ; \mathrm{n}=$ 23; Fig. 5). Thus, the final yields of cultures grown during warmer months are well predicted by the original in situ abundances. The highest yields were obtained from samples collected at the lowest in situ temperatures, during winter and early spring.

The first nutrient addition experiment (June 1995) showed that neither phosphorus alone, nor nitrogen plus phosphorus addition, increased final yields. At both stations, mid- and lower bay, there were no significant differences among treatments (ANOVA, $\mathrm{p}>0.05$ ) (Fig. 6). In a similar experiment in July 1995, the nitrogen plus phosphorus treatment approximately doubled yield at the mid-bay site but not the lower bay site (ANOVA, $\mathrm{p}<$ 0.01). The nutrient experiment in August 1995 had a different design. For this experiment, we added nutrients after the initial $72 \mathrm{~h}$ incubation period. Over an additional $72 \mathrm{~h}$, bacterial abundance declined in the control 

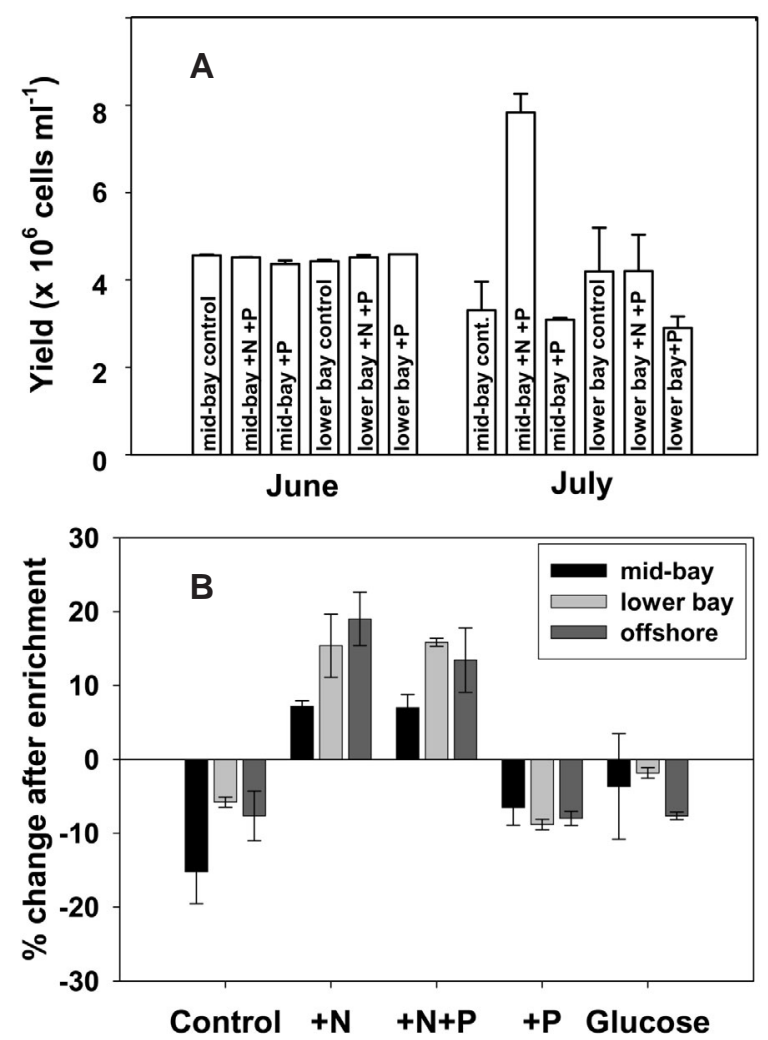

Fig. 6. Nutrient enrichment seawater culture experiments for (A) June 1994 and July 1994, and (B) August 1995

treatment ( 5 to $15 \%$ reduction), likely due to grazing by nanoflagellates. Although we filtered the water to remove grazers from the inoculant, even a few getting through would have grown enough after 3 to $5 \mathrm{~d}$ to graze the bacteria. Treatments that were enriched with nitrogen, or nitrogen plus phosphorus, exhibited additional growth (8 to $21 \%$ beyond initial yield; ANOVA, p < 0.01). Treatments enriched with phosphorus alone, or glucose, responded similarly to the controls, losing 2 to $10 \%$ of initial abundances (Fig. 6). The trends were the same for the mid-bay, lower bay and offshore stations.

\section{DISCUSSION}

Abundance and productivity of bacterioplankton in Mobile Bay are broadly similar to such values observed in other estuaries around the world, including more intensively sampled estuaries on the US east coast (Table 1; see also review by Ducklow \& Shiah 1993). A comparison with results from Chesapeake Bay indicates some of the similarities and also reveals some differences. For example, Ducklow \& Shiah (1993) reported that $91 \%$ of their samples in Chesapeake Bay (>2000 mid-Bay samples) had bacterial abundances greater than $2 \times 10^{9}$ cells $\mathrm{l}^{-1}$. In our much smaller sample size the result was the same; 92 of 101 surface samples contained bacteria at abundances that exceeded this level. The seasonal range in bacterial abundance in the Chesapeake was much greater, however, being more than a factor of $40(\sim 0.5$ to $20 \times$

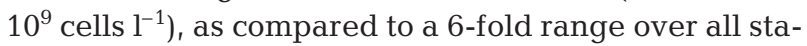
tions in our 17-mo study in Mobile Bay (1.3 to $7.3 \times 10^{9}$ cells $\left.\mathrm{l}^{-1}\right)$. Bacterial productivity also varied over a narrower range in Mobile Bay when compared to the Chesapeake. Ducklow \& Shiah (1993) reported a thousand-fold range in bacterial productivity ( 0.48 to $480 \mathrm{mg} \mathrm{C} \mathrm{m} \mathrm{m}^{-3} \mathrm{~d}^{-1}$ ), while our measurements varied only about 10 -fold (14 to $179 \mathrm{mg} \mathrm{C} \mathrm{m}^{-3} \mathrm{~d}^{-1}$ ). The ranges in these properties in Chesapeake Bay were repeated in multiple years, making it doubtful that the extremes are due simply to more extensive sampling.

The winter water temperature minimum likely contributes the most to the differences in bacterial abundance and productivity between Mobile Bay and the Chesapeake. The Chesapeake annual temperature minimum is close to $0^{\circ} \mathrm{C}$, with some portions of the Bay freezing each winter. Mobile Bay seldom gets below $10^{\circ} \mathrm{C}$. Because bacterial metabolism is more sharply curtailed near the freezing point of water, compared to eukaryotes (Pomeroy \& Deibel 1986, Pomeroy \& Wiebe 2001), it is likely that winter bacterial populations will be more strongly reduced by grazing and other losses

Table 1. Abundance and productivity of bacterioplankton in US east coast estuaries. In all cases, estuaries were sampled over an annual cycle for at least $1 \mathrm{yr}$, and all studies used the thymidine incorporation method to estimate bacterial production rates. Residence times are from Dettmann (2001) (Delaware, Narragansett, and Chesapeake bays), P. Gay \& J. O'Donnell (pers. comm.) (Long Island Sound), and Pennock et al. (1994) (Mobile Bay). Volume-based productivity values for Delaware Bay were calculated from the reported areal values in Hoch \& Kirchman (1993), divided by an average depth of $9 \mathrm{~m}$ for the Bay (Dettmann 2001)

\begin{tabular}{|c|c|c|c|c|}
\hline Estuary & $\begin{array}{c}\text { Abundance } \\
\left(\times 10^{6}{\left.\text { cells } \mathrm{ml}^{-1}\right)}^{-}\right.\end{array}$ & $\begin{array}{l}\text { Productivity } \\
\left(\mathrm{mg} \mathrm{C} \mathrm{m}^{-3} \mathrm{~d}^{-1}\right)\end{array}$ & $\begin{array}{l}\text { Residence } \\
\text { time }\end{array}$ & Source \\
\hline Chesapeake Bay & $0.5-25$ & $0.48-480$ & $7.6 \mathrm{mo}$ & Ducklow \& Shiah (1993) \\
\hline Delaware Bay & $<0.7-13$ & $1.5-184$ & $3.3 \mathrm{mo}$ & Kirchman \& Hoch (1988), Hoch \& Kirchman (1993) \\
\hline Long Island Sound & $0.3-14$ & $0.9-361$ & $3 \mathrm{mo}$ & J. A. Fuhrman (unpubl.) \\
\hline Narragansett Bay & $0.4-7.5$ & $1.4-148$ & $26 \mathrm{~d}$ & Staroscik \& Smith (2004) \\
\hline Mobile Bay & $1.3-7.3$ & $14-179$ & $17 \mathrm{~d}$ & Present study \\
\hline
\end{tabular}


in higher-latitude temperate estuaries than in subtropical or warm-temperate ones. Narragansett Bay, Long Island Sound, and Delaware Bay, 3 other large estuaries from the US east coast (Table 1), also have winter temperature minima near $0^{\circ} \mathrm{C}_{i}$ they also have much lower minima in bacterial abundance and productivity, compared to Mobile Bay.

Temperature provided the strongest correlation with bacterial abundance and productivity in our study (Fig. 7). Neither bacteria parameter was significantly correlated with DOC, DON, or phytoplankton production. Even though Mobile Bay winter water temperatures never approach the freezing point, it is clear that bacterial activity is slowed by the low temperatures experienced then. Bacterial abundance increased rapidly as temperatures exceeded $15^{\circ} \mathrm{C}$, even though the annual maximum in discharge at that time increases the rate of export of bacterial cells. Because temperature transitions in the Bay occur rapidly, our
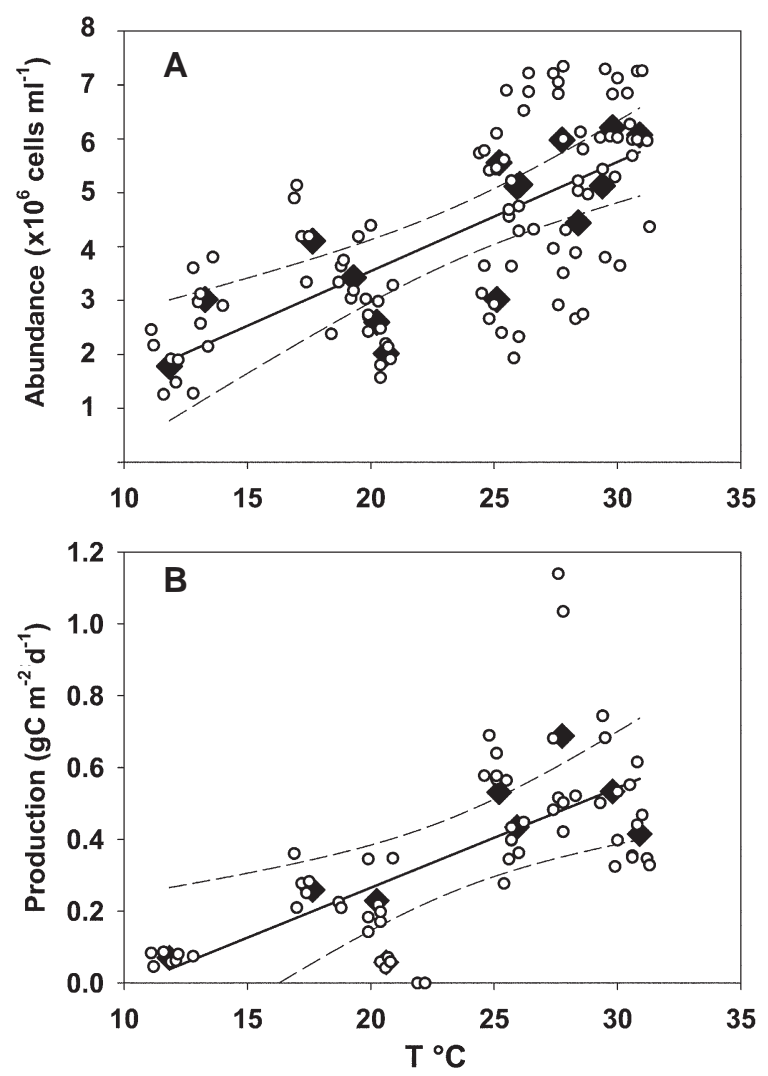

Fig. 7. Relationship between (A) bacterial abundance and temperature, and (B) production and temperature, for the whole study. Individual data points are shown (O) . To avoid autocorrelation, data were averaged within sampling dates $(\diamond)$ before regressions were calculated. Dashed lines are 95\% confidence intervals for the slopes. Equations are: Cells ml ${ }^{-1}=$ $-512209+202816 \times$ Temperature $\left(\mathrm{r}^{2}=0.65 ; \mathrm{n}=14 ; \mathrm{p}<0.01\right)$; and Production $=-0.291+0.028 \times$ Temperature $\left(\mathrm{r}^{2}=0.63\right.$;

$$
\mathrm{n}=9 ; \mathrm{p}<0.05)
$$

data are clustered into 3 temperature ranges, roughly between 12 and $13^{\circ} \mathrm{C}$ (winter), 17 and $21^{\circ} \mathrm{C}$ (spring/ fall), and above $24^{\circ} \mathrm{C}$ (summer; Fig. 7). Although the overall relationships between bacteria and temperature are positive, the correlations for both abundance and productivity are non-existent or weak within each temperature range (Fig. 7). Thus, over small temperature ranges, temperature effects are commensurate with other factors that potentially regulate bacterioplankton, including substrate quality, inorganic nutrient availability, and mortality.

Neither bacterial abundance nor productivity showed a strong relationship with salinity in our study. For our 15 sampling dates, bacterial abundance was only significantly correlated with salinity twice (April 1994 and January 1995; data not shown). On both occasions the correlation was positive. This is counter to results reported in the York River, a subestuary of Chesapeake Bay, where bacterial abundance consistently increases with salinity (Ducklow et al. 2000, Schultz \& Ducklow 2000, Schultz et al. 2003) and to those from the Schelde estuary, where bacterial abundance and productivity both decreased as salinity increased (Goosen et al. 1997). We also observed no evidence of a biomass maximum at intermediate salinities, as reported for Chesapeake Bay and the Mississippi River outflow plume (Ducklow et al. 2000, Pakulski et al. 2000). Neither bacterial production nor thymidine uptake per cell was correlated with salinity, again counter to observations from the York River, where productivity declined as freshwater mixed down estuary with saline water (Ducklow et al. 2000).

We used an experimental approach to evaluate the nature and degree of resource limitation of bacterial activity in Mobile Bay. In our 'seawater cultures', we always obtained growth in the absence of grazers. Even though the source of autochthonous DOC was removed by filtering out phytoplankton and incubating in the dark, bacteria grew back to in situ levels at rates similar to those estimated with the thymidine technique (i.e. 0.5 to $2 \mathrm{~d}^{-1}$ ). Thus labile resources for bacterial growth were always present in the bay. Probably our most surprising result is that, during warmer months $\left(20^{\circ} \mathrm{C}\right.$ or greater), bacterial populations in the cultures grew back to in situ levels (Fig. 5) across the whole range of abundances found in our samples. We can think of no reason why this should be so, but it emphasizes that bacterial populations in the bay have enough resources to at least double their populations, growing at their in situ rates, even without additional flux of DOC from phytoplankton. It also indicates that autochthonous DOC must be the main source of substrate for bacteria, because the in situ resource levels suggested by the seawater cultures are only equal to about 1 bacteria generation, whereas the residence time of bacteria in 
the bay is much longer. For an estuary like Mobile Bay, where seasonal and episodic freshwater inputs, and subtidal exchanges of water with the adjacent shelf are highly variable, estimating residence times can be difficult. Wiseman et al. (1988) estimated that the residence time due to subtidal exchange was of the same order as that due to gravitational circulation and freshwater dilution (several weeks; Pennock et al. 1994, Solis \& Powell 1999), and shorter than tidally driven exchanges (ca. 2 mo; Austin 1954). Thus, bacterial populations spend at least a week (several generations) in the bay during their transit across the salinity gradient, and phytoplankton-derived DOC must thus replenish any watershed-derived material utilized during that time. Many other studies have also indicated the importance of autochthonous sources of substrate for estuarine bacterial populations (Sobczak et al. 2002, Staroscik \& Smith 2004).

During times when temperatures in the bay were below $20^{\circ} \mathrm{C}$, yields in the seawater cultures were much higher than in situ abundances (Fig. 5). This suggests that labile DOC accumulates, relative to bacterial biomass, during winter. This interaction between resource supply and temperature also suggests that watershedderived organic matter is more likely to be exported onto the shelf during winter. This could lead to high variability among years in the degree of trophic coupling between estuary and shelf, with organic matter being exported as DOC in years when temperature minima and discharge are more nearly synchronous, or as bacterial biomass in years when peak discharge occurs later in the spring.

During our study, DOC concentrations did not show a strong relationship with salinity. Although DOC was almost always higher in the upper bay, among fifteen sampling dates, DOC and salinity were significantly correlated only 6 times. In every case, the correlation was negative and there was no evidence of non-conservative behavior (intermediate concentrations falling consistently above or below the line connecting endmembers; data not shown). This suggests again that autochthonous DOC is the main substrate for bacterial growth. At a concentration of $5 \times 10^{9}$ cells $\mathrm{l}^{-1}$ and a carbon content of $20 \mathrm{fg} \mathrm{C} \mathrm{cell}^{-1}$ (Lee \& Fuhrman 1987), bacterial biomass in the bay would be about $8 \mu \mathrm{mol} C$ $\mathrm{l}^{-1}$. If this biomass has a generation time of about $1 \mathrm{~d}$, as the thymidine measurements suggest, then bacterial DOC utilization during a $10 \mathrm{~d}$ transit through the bay is on the same order as in situ DOC concentrations. For example, at those levels of biomass and growth, with a conservative growth efficiency of 0.5 , bacterial carbon

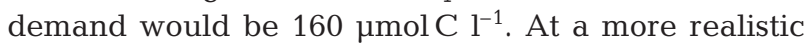
growth efficiency of 0.2 (del Giorgio \& Cole 1998),

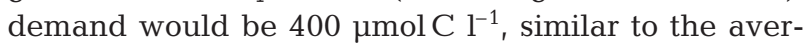

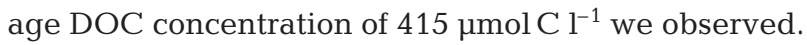

The fact that DOC concentration does not decline at a rate faster than that predicted from mixing alone indicates that autochthonous sources at least keep up with bacterial demand; our seawater culture results indicate that they usually exceed it, creating a 'reserve' of DOC for bacterial growth or export onto the shelf.

The final yields of the seawater cultures can be used to estimate variations in the fraction of DOC that is labile on the time scale of the incubations (4 d). Assuming a carbon content of $20 \mathrm{fg} \mathrm{C} \mathrm{cell}^{-1}$ to convert the cell yields to carbon production (Lee \& Fuhrman 1987), the estimated average percentage of total measured DOC that was utilized by bacteria during the incubations was $14.1 \%\left( \pm 5.8 \quad \mathrm{SE}_{;} \mathrm{n}=29\right)$ or $5.7 \%( \pm 2.3)$ for assumed gross growth efficiencies of 0.2 or 0.5 , respectively. There was no clear trend in percentage labile DOC with either time or temperature. During the summer, percentage labile DOC may be higher than estimated this way because our nutrient addition experiments showed that inorganic $\mathrm{N}$ could increase carbon utilization (yield) then.

It is clear from our data that, in Mobile Bay, temperature is important in limiting bacterial growth during winter. Given the fact that bacteria always grew at least back to in situ levels in the seawater cultures, the amount of resources available in situ had to be 2 to $5 \times$ bacterial biomass (for gross growth efficiencies of 0.5 and 0.2 , respectively). We did not measure the effects of added resources on growth rates directly, but it seems likely that the quality of the organic substrates was the key factor for most of the year. During summer, we observed that inorganic nitrogen increased yields in the seawater cultures in 4 out of 7 experiments, but since there were no controls that did not grow, we infer that this limitation did not have any effect over the first few divisions and thus was not important in situ. Also, since inorganic $\mathrm{N}$ and $\mathrm{P}$ concentrations were lowest in summer, this is a worst-case estimate of the role of these nutrients in regulating bacterial growth. It does seem surprising that $\mathrm{N}$ and not $\mathrm{P}$ should stimulate increased yield in these cultures, in which the bacteria have been separated from sources of recycled nutrients. Total N:total P in Mobile Bay is almost always greater than 10, the ratio in bacterial cells (Fig. 3D). Possibly, more of the $\mathrm{N}$ is in chemical forms that are inaccessible to bacteria, compared to the P. Also, regenerated $\mathrm{N}$ from the benthos of this shallow system may be important for bacterial growth (Cowan et al. 1996). Separating the bacteria from this flux during the incubations would result in a deficit of $\mathrm{N}$.

Overall, abundances of bacteria in Mobile Bay are relatively low compared to other estuarine systems (e.g. maximum abundance in Mobile Bay is ca. $1 / 3$ of the maximum in Chesapeake Bay). Because excess resources for growth are present in situ year round, as 
indicated by the seawater culture results, we conclude that loss processes control the abundance of bacteria in the bay. The residence time is several-fold greater than bacterial generation time. Thus, even though washout must be a significant loss, especially when growth is slowed by temperature in winter, mortality due to grazing or other factors must be the main factor keeping populations low. Our observations in Mobile Bay are consistent with trophic models suggesting that bacteria in eutrophic systems, such as estuaries, are grazed well below the carrying capacity of their environments (Fenchel 1986, Sanders et al. 1992). In the case of Mobile Bay, this feature of the microbial food web likely results in export of labile organic matter onto the shelf. Given the close proximity of oligotrophic waters in the northern Gulf of Mexico (e.g. the tropical Loop Current and its meanders), it would be interesting to know how this export affects trophic structure on the shelf and deep waters beyond.

Acknowledgements. We thank the staff of the Dauphin Island Sea Lab, especially J. Cowan, J. Lehrter, L. Stanton, S. McLeroy, B. Jones, A. Wagner and A. Foster for technical and field support. We thank J. O'Donnell, P. Gay, and J. Fuhrman for the use of unpublished data. This research was supported by the US National Science Foundation through Alabama EPSCoR.

\section{LITERATURE CITED}

Ammerman, JW, Fuhrman JA, Hagstrom A, Azam F (1984) Bacterioplankton growth in seawater: I. Growth kinetics and cellular characteristics in seawater cultures. Mar Ecol Prog Ser 18:31-39

Austin GB (1954) On the circulation and tidal flushing of Mobile Bay, Alabama. Part 1. Technical Report No. 12. Texas A \& M College Research Foundation Project 24, College Station, TX

Bell RT (1993) Estimating production of heterotrophic bacterioplankton via incorporation of tritiated thymidine. In: Kemp PF, Sherr BF, Sherr EB, Cole JJ (eds) Handbook of methods in aquatic microbial ecology. Lewis Publishers, Ann Arbor, MI, p 495-503

Cowan JLW, Pennock JR, Boynton WR (1996) Seasonal and interannual patterns of sediment-water nutrient and oxygen fluxes in Mobile Bay, Alabama (USA): regulating factors and ecological significance. Mar Ecol Prog Ser 141: $229-245$

Daneri G, Riemann B, Williams PJL (1994) In-situ bacterial production and growth-yield measured by thymidine, leucine and fractionated dark oxygen-uptake. J Plankton Res 16:105-113

del Giorgio PA, Cole JJ (1998) Bacterial growth efficiency in natural aquatic systems. Annu Rev Ecol Syst 29:503-541

Dettmann EH (2001) Effect of water residence time on annual export and denitrification of nitrogen in estuaries: a model analysis. Estuaries 24:481-490

Ducklow HW, Shiah F (1993) Bacterial production in estuaries. In: Ford TE (ed) Aquatic microbiology, an ecological approach. Blackwell Scientific, Oxford, p 261-287
Ducklow H, Schultz G, Raymond P, Bauer J, Shiah F (2000) Bacterial dynamics in large and small estuaries. In: Bell CR, Brylinsky M, Johnson-Green M (eds) Microbial biosystems: new frontiers. Atlantic Canada Society for Microbial Ecology, Halifax, p 105-112

Fenchel $\mathrm{T}$ (1986) The ecology of heterotrophic flagellates. Adv Microb Ecol. 9:57-97

Fuhrman JA, Azam F (1982) Thymidine incorporation as a measure of heterotrophic bacterial production in marine surface waters: evaluation and field results. Mar Biol 66: 109-120

Goosen NK, vanRijswijk P, Kromkamp J, Peene J (1997) Regulation of annual variation in heterotrophic bacterial production in the Schelde estuary (SW Netherlands). Aquat Microb Ecol 12:223-232

Guo L, Santschi PH, Bianchi TS (1999) Dissolved organic matter in estuaries of the Gulf of Mexico. In: Bianchi TS, Pennock JR, Twilley RR (eds) Biogeochemistry of Gulf of Mexico estuaries. John Wiley \& Sons, New York, p 269-299

Hobbie JE, Daley RJ, Jasper S (1977) Use of Nuclepore filters for counting bacteria by fluorescence microscopy. Appl Environ Microbiol 33:1225-1228

Hoch MP, Kirchman DL (1993) Seasonal and inter-annual variability in bacterial production and biomass in a temperate estuary. Mar Ecol Prog Ser 98:283-295

Kirchman DL, Hoch MP (1988) Bacterial production in the Delaware Bay estuary estimated from thymidine and leucine incorporation rates. Mar Ecol Prog Ser 45:169-178

Kirchman DL, Keil RG, Wheeler PA (1989) The effect of amino acids on ammonium utilization and regeneration by heterotrophic bacteria in the subarctic Pacific. Deep-Sea Res 36:1763-1776

Lee S, Fuhrman JA (1987) Relationship between biovolume and biomass of naturally-derived marine bacterioplankton. Appl Environ Microbiol 53:1298-1303

Pace ML, Cole JJ (1996) Regulation of bacteria by resources and predation tested in whole-lake experiments. Limnol Oceanogr 41:1448-1460

Pakulski JD, Benner R, Whitledge $T$, Amon R, Eadie $B$, Cifuentes L, Ammerman J, Stockwell D (2000) Microbial metabolism and nutrient cycling in the Mississippi and Atchafalaya River plumes. Estuar Coast Shelf Sci 50: 173-184

Pennock JR, Sharp JH (1986) Phytoplankton production in the Delaware Estuary: temporal and spatial variability. Mar Ecol Prog Ser 34:143-155

Pennock JR, Sharp JH, Schroeder WW (1994) What controls the expression of estuarine eutrophication? Case studies of nutrient enrichment in the Delaware Bay and Mobile Bay estuaries, USA. In: Dyer KR, Orth RJ (eds) Changes in fluxes in estuaries. Olsen \& Olsen, Fredensborg, p 139-146

Pomeroy LR, Deibel D (1986) Temperature regulation of bacterial activity during the spring bloom in Newfoundland coastal waters. Science 233:359-361

Pomeroy LR, Wiebe WJ (2001) Temperature and substrates as interactive limiting factors for marine heterotrophic bacteria. Aquat Microb Ecol 23:187-204

Sanders RW, Caron DA, Berninger U (1992) Relationships between bacteria and heterotrophic nanoplankton in marine and fresh waters: an inter-ecosystem comparison. Mar Ecol Prog Ser 86:1-14

Schroeder WW, Wiseman WJ (1986) Low-frequency shelfestuarine exchange processes in Mobile Bay and other estuarine systems on the northern Gulf of Mexico. In: Wolfe DA (ed) Estuarine variability. Academic Press, 
New York, p 355-367

Schultz GE, Ducklow H (2000) Changes in bacterioplankton metabolic capabilities along a salinity gradient in the York River estuary, Virginia, USA. Aquat Microb Ecol 22: 163-174

Schultz GE, White ED, Ducklow HW (2003) Bacterioplankton dynamics in the York River estuary: primary influence of temperature and freshwater inputs. Aquat Microb Ecol 30: $135-148$

Sobczak WV, Cloern JE, Jassby AD, Muller-Solger AB (2002) Bioavailability of organic matter in a highly disturbed estuary: the role of detrital and algal resources. Proc Natl Acad Sci USA 99:8101-8105

Solis RS, Powell GL (1999) Hydrography, mixing characteristics, and residence times of Gulf of Mexico estuaries. In: Bianchi TS, Pennock JR, Twilley RR (eds) Biogeochemistry

Editorial responsibility: Robert Sanders,

Philadelphia, Pennsylvania, USA of Gulf of Mexico estuaries. John Wiley \& Sons, New York, p 29-61

Sondergaard M, Middelboe M (1995) A cross-system analysis of labile dissolved organic carbon. Mar Ecol Prog Ser 118: 283-294

Stanier RY, Doudoroff M, Adelberg EA (1970) The microbial world. Prentice Hall, Englewood Cliffs, NJ

Staroscik AM, Smith DC (2004) Seasonal patterns in bacterioplankton abundance and production in Narragansett Bay, Rhode Island, USA. Aquat Microb Ecol 35:275-282

Strickland JD, Parsons TR (1972) A practical handbook of seawater analysis, Vol 167. Fisheries Research Board of Canada, Ottawa

Wiseman WJ, Schroeder WW, Dinnel SP (1988) Shelf-estuarine water exchanges between the Gulf of Mexico and Mobile Bay, Alabama. Am Fish Soc Symp 3:1-8

Submitted: July 12, 2004; Accepted: September 19, 2004

Proofs received from author(s): October 22, 2004 